\title{
Impact of Online Media on Print Media in Developing Countries
}

\author{
Caroline Kalombe ${ }^{1}$, Jackson Phiri ${ }^{2}$ \\ ${ }^{1}$ Graduate School of Business, University of Zambia, Lusaka, Zambia \\ ${ }^{2}$ Department of Computer Sciences, School of Natural Sciences, University of Zambia, Lusaka, Zambia \\ Email: djcalina@gmail.com, jackson.phiri@cs.unza.zm
}

How to cite this paper: Kalombe, C. and Phiri, J. (2019) Impact of Online Media on Print Media in Developing Countries. Open Journal of Business and Management, 7 , 1983-1998.

https://doi.org/10.4236/ojbm.2019.74136

Received: September 2, 2019

Accepted: October 19, 2019

Published: October 22, 2019

Copyright $\odot 2019$ by author(s) and Scientific Research Publishing Inc. This work is licensed under the Creative Commons Attribution International License (CC BY 4.0).

http://creativecommons.org/licenses/by/4.0/

\begin{abstract}
The newspaper industry must continue to innovate and find ways in which to harness technology and employ business models that will not only help it save costs but also increase revenue for the firms. The aim of this study was to identify the major challenges based on Miles and Snow on how online media is impacting print newspapers revenue in developing countries and how these challenges could be addressed in order to improve print newspapers revenue collection. The study focused on Zambia a country in Southern Africa. The study was based on a population drawn from seven print media houses in Zambia, five from the private sector and two from the government. The participants include the Zambia Daily Mail and Times of Zambia from the public sector. The other five from private sector include the Daily Nation Newspaper, the Mast, the Voice, News Diggers Newspaper, and the New Vision. The study used a questionnaire as a research instrument with a population of 180 and the response rate of $56.1 \%$ to collect the quantitative data. SPSS version 20 was used to analyze quantitative data based on descriptive statistics, correlation and regression. The results indicate that, the threat of online media on printed media in developing countries is growing. The statistical computed value from Pearson Chi-Square test $\mathrm{P}$-value of 0.034 which was less than $5 \%$, indicate the positive influence of lower cost of E-paper through the subscription pricing and how this eventually affects the print media pricing, sales and revenue collection. The results also show that E-Papers are cheaper through subscription and easy to access by the mases as the cost of the Internet continues to decline. This is reduction in circulations and revenue from advertisement as most advertisers are now focused on online media platform where they are able to reach clients through various platforms. These factors have led to notable reduction in print media sales as readers flock to online media platforms, thereby, reducing circulation of newspapers.
\end{abstract}




\section{Keywords}

Print Newspapers, Online Media, Convergence, Miles and Snow Framework, Zambia Media, Electronic Media

\section{Introduction}

Convergence and online media have changed the way in which people communicate leading to disruptions in the newspaper industry in Zambia which has largely remained traditional in the way it conducts its business. Online media has shown that the industry needs to evolve in order to remain competitive in the information provision sector. Technological advancements have changed the way in which many people interact [1]. People want to interact and communicate quicker and digital platforms are offering them this opportunity [2]. As people become busier by the day, the need for information is also growing and they want it by the click of a finger [1] [2]. The shift to the digital platform has changed the way in which people consume and use information [3]. For a country like Zambia, which is considered as a least developed country, access to information is important for development decisions to be made [4]. The rest of the paper is arranged as follows. In Section 2, the paper highlights the literature review while the methodology is in Section 3. The results are given in Section 4 while the discussion and conclusion in Section 5. The recommendations from the study are given in Section 6.

\section{Literature Review}

This section looks at the background and role the new media plays in the dissemination of news and information. It also interrogated the impact of online and print media in developing countries and the impact on businesses based on some key strategies and business models.

\subsection{The Birth of New Media}

The first newspaper service online was America Online, launched by the Chicago Tribune in May 1992 [5]. In 1995, the online newspaper concept of today was developed, featuring among others $\mathrm{CNN}$ as a global news engine. Six years later, in April 2001, American trade Journal Editor and Publisher Interactive had registered in its database 12,878 news media online [5]. Most newspapers have been watching their circulation turn into a continuously negative sloping line since the mid-1960s, when television entered the households of the average family, and with it, televised news in Westernized societies [6]. With the rise of new media such as broadband, wireless internet, and increasingly sophisticated mobile technology, it leaves one thinking how the future of the political media economy in this digital age will pan out [7] [8]? Unfortunately, "the delicate balance between public responsibility and private profit has been steadily tipping 
in favor of the latter" [9].

This explosion of technology has provided consumers with a constant source to news and entertainment in developing countries. This has also seen various marketing and advertisements platforms that have emerged in the past decade [10]. More than two thirds of all domestic news revenue comes from advertising, roughly an amount of US \$43 million for US newspapers from 2014 [11].

\subsection{Media Convergence and Online Journalism}

The pressures of communication and the information revolution in the mid-nineties compelled the journalism educators to debate alternate models of curriculum. They found the answer in convergence. There are different connotations of the term, "Convergence". It is defined and interpreted here within the realms of journalism. Convergence in journalism is referred to as, "multiple-platform publishing" or as "integrated journalism" [12]. The speed of adoption and diffusion of innovations in the contemporary media industry is posing a great challenge to media educators as the newsroom appears to be constantly ahead of the classroom, especially in the developing world [13]. [14] notes that for the newspaper industry, media convergence represents enormous challenges but also possibilities to use new platforms and content to serve new consumer needs. Characterized by the rise of the Internet, the digitalization of information and the dissipation of boundaries between media platforms, convergence changes the socio-economic field in which newspaper publishers operate. In a broad sense, media convergence refers to the general trend where the boundaries between previously separate sectors of media, telecommunications and information technology have become increasingly blurred and different sectors of the media industry have become more interconnected.

[15] adds that online circulation of traditional newspapers is growing. The use of social media and social networks is increasing rapidly worldwide. In November 2011, the popular social network, Facebook had more than 800 million active users, 75 percent of which are based outside the United States. More than 50 percent of those 800 million people log on to Facebook in any given day. At the same time, Internet and mobile technologies are at the center of how people's relationship to news is changing. The importance of social networks for news consumption is growing. Moller in [15] goes on to state that people use their social networks and social networking technology to filter, assess and react to news. This convergence is particularly promoted by the Internet and the digitalization of all media content, but its implications can be discussed on several levels, including technologies, industries, media contents and journalistic practices. For newspapers, convergence has created possibilities to create content that combines different multimedia elements (text, photographs, audio, video, graphics, social networks, etc.) and to distribute these products across different media platforms [15].

Convergence has led to the creation of technologies which have helped advertisers improve their sales; this is because multimedia platforms provide advertis- 
ers with various platforms on which to engage their audience thereby, increasing reach through online resources like video advertisements on online resources). However, the effects can also be negative due to fragmentation of the audience and the disruption of established business models [16]. The effects of the emergence and continuous development of the Web 2.0 can be seen in all aspects of life-socially, culturally, politically and economically. Advertising and marketing methods have been changed to suit the online platforms and audience preferences. In the past, companies predominately would have had advertisements displayed on billboards, in magazines and catalogues, seen on television and heard on the radio. While these mediums are still in use today, the Internet has allowed for the development and explosion of new methods of advertising, which can be distributed to a much larger group than ever possible before [17].

It can therefore be noted in a summary that as people become busier, they require information at their convenience. Thus, the physical space for news is shrinking as people look to social media platforms as sources of news. This has prompted newspapers companies to follow the audience where they are in a bid to maintain readership and hence, increase sales.

\subsection{Convergence in Developing Countries}

In Zambia information technologies, such as mobile phones and the internet, are used with radio and television broadcasts to enable audiences contribute ideas and opinions on the public issues [18]. In contrast to Kenya and other African countries, such as South Africa and Nigeria, Zambia has a relatively low level of mobile phone access. According to [19] and [20], the uptake of mobile phones has still been considerable. For example, the number of mobile phone subscribers in Zambia increased from 98,853 in 2000 to 10,395,801 in 2013 [21].

The number of fixed line subscribers has fluctuated; for example, there were 83,326 fixed line subscribers in 2000, dropping to 82,542 in 2012, and then rising to 115,762 in 2013 (ITU, 2014). Mobile phone technology has changed the way in which users engage with the media, as people can use their mobile phones to access broadcast media through phone-in and text-in, as well as access radio [22]. Increasingly, access to "smart" phone handsets and 3G signals, including phones with some free internet access, for example through Facebook applications, provides new opportunities for participation. While access to mobile phones has been increasing, Zambia continues to have one of the lowest levels of internet connectivity on the African continent at 0.79 internet users per 100 inhabitants in 2013 [23].

Zambia has eight (8) main print media publications, namely the Zambia Daily Mail Limited (ZDML), Times of Zambia (TOZ), the News Diggers, The Mast, The Sun, The Voice, New Vision and the Daily Nation Newspapers (DN). The core business of these companies is publication of print media (newspapers). Two (2) of these papers (The Zambia Daily Mail and the Times of Zambia) are state owned through the Industrial Development Corporation which now has an oversight role of ensuring state owned enterprises operate profitably, while the 
others are privately owned. All the main newspapers named above, introduced the electronic version of the newspapers at different times and were therefore publishing both versions of the papers.

[24] reports that the introduction of the e-Paper by the Times of Zambia was as a result of the media institution's effort to adapt to the technological advancements and shift of readers to social media platforms as sources of news. The report goes on to state that the reason behind the company's introduction of the e-Paper was that it was part of an innovative action of enhancing product delivery amidst tight competition in the media industry. Sandi in [24] further indicated that the company had signed a memorandum of understanding (MoU) with one of the mobile service providers to enable its subscribers make payments through the Mobile Money system.

Many people in urban areas spend time online using various devices, and as people are become busier they require information faster. While reliable information is still scarce, survey results seem to suggest that there are more urban users of mobile phones and internet than rural users. Further, men as opposed to women are more likely to own a mobile phone [25]. High uptake of mobile phones is not without challenges. Some survey results suggest mobile phone users face difficulties tied to lack of phone credit, poor reception or connectivity, and lack of power to charge mobile phone batteries [19]. The use of the internet on the phone is rare, partly because few mobile subscribers can afford the more expensive phones with this feature [25].

The Zambia Daily Mail developed and introduced its electronic version of the newspaper in the year 2015 [26]. This report states that the e-Paper was introduced to meet its different audiences, i.e. students and the working class among others. The News Diggers on the other hand, started as an online publication before developing a printed version of the paper [25]. The publication is multimedia and was birthed right after The Post Newspaper was placed under receivership in 2016 and later liquidated in 2018. The Post Newspapers was Zambia's leading privately owned newspapers. The Mast Newspapers however, is the sister company of the liquidated Post Newspapers. The paper was placed on the market in 2016 when the Post Newspapers was placed under receivership. The Mast Newspaper later introduced an online version of the paper to reach a wider audience as it was failing to make sales of its paper version [25].

All these print media houses provide similar content of its paper version but adopt different ways in which content can be accessed. Readers have to subscribe to some of these papers to get full content, while some of them provide content for free. This has created instability in the market because clients are now used to getting information for free and have to think twice before wanting to pay for it. The Daily Nation newspaper provides content online and also has a provision for subscription.

\subsection{Threat on Print Media in Developing Countries}

The increase in online platforms providing news content has been noted to re- 
duce print newspaper circulations. Various authors have analyzed how online media is threatening the survival of print newspapers world over. [27] for example in his study established that people easily access news online for free and that this makes it difficult for them to pay any subscriptions to a newspaper. The witness of not the "End" of print but rather the adaptation of print and News organizations to rapidly changing consumer patterns and a corresponding shift towards digital content has brought the new media to create its impact on the society at a faster pace. The study indicated that access to online news impacts revenue to the extent that it is free. It however, does not show how online media can be harnessed as a business to supplement revenue for the traditional print paper. Due to the availability of internet communications, the students get information easily. Some of the major reasons concluded from this study is there is a lack of time to read newspapers and availability of other major communication resources. Majorly this e-news is considered as time consuming. Finally, the study concluded that the online news has highly satisfied the reader's expectations and also reduced the print newspapers circulation. This is major reason of the proliferation of e-newspapers over the traditional newspapers in UAE [27]. However, this study did not highlight what models can be employed by traditional newspapers to increase revenue.

A study [28] conducted which was aimed at assessing the migration trends from printed newspapers to online sources of news. The goal was to assess factors influencing this migration and the impact of this migration on advertising revenue. This study noted that there is no significant change in advertising revenues of printed newspapers although a significant part of the readership has migrated from printed newspapers to online news. Most printed newspapers have adopted survival strategies such as pursuing a dedicated online publishing strategy, newspaper organizational restructuring, and diversification from print to other media platforms. However, this was not adequately proved because newspaper revenue is dependent on circulation. This is because other studies highlighted above have shown that people migrate to online media because it is not only quicker but because it is free. Therefore, what model is employed by Zambian newspapers to survive?

The threat of online media on printed newspapers has been observed in many studies and some have shown that "newspaper readership has been slipping for decades; market fragmentation has meant fewer viewers for any one television news program and fewer readers for any one magazine. Efforts at newsroom 'convergence,' as well as the ongoing commitment to online formats that have now lost money for years, indicate media corporations if not necessarily the journalists within them, have accepted the reality that online news delivery is not going away," [29]. However, in this study, Singer focused on journalism as profession. This was about, how news was gathered, stored and disseminated. It was not so much on whether the newspapers would survive but how traditional journalism could remain in the work of online journalism. 


\subsection{Related Works}

[30] notes that the revolution happening in the information sector brings excitement as well as challenges in journalism practice and digital space. This revolution has been exacerbated by constant technological changes and innovations. This study indicates that there is shift in the dissemination of information as more people will look to digital platforms to get information and that the journalism practice and publishing industry needs to come on board. It shows that print newspapers will need to use technology in order to survive. The study, however, does not show this threat will affect the collection of revenue by newspaper and how the online media can be harnessed to enable newspapers not only broadens its readership but also increase revenue.

The digital newspaper needs to be improved with a focus on making use of the available space adequately to provide a more detailed newspaper that can be depended upon as an alternative to the print newspaper. There must be every effort to ensure timely uploads of the online newspaper as may be satisfactory to the readers with a specific focus on accuracy of the news presented [31]. However, this study sought to establish the extent to which presentation of content in the print newspaper compares with that of the online version. It focused on the differences between the content of the hard copy newspaper and that of the online platform. It did not provide findings on whether the presentation of information on online media platform would threaten the existence or business of traditional newspapers. It focuses on including more content on online media but does not address the strategy that print newspapers would employ to increase readership and revenue. [32] observed that from 2000, the economic downturn caused a decline in online advertising revenue on the other hand; e-commerce never fulfilled its promise. Thus, a number of online news publishers have been reconsidering subscription models as a last resort for survival. Some have re-developed the model and many more may follow suit. This study established the concept of subscription for online newspapers to collect some revenue from readers. However, it does not state how this will help print newspapers as often people want to access online information for free. At what price will the developing countries audience accept to buy information or news online?

\subsection{Miles and Snow "Adaptive Cycle" Framework}

The dynamic environment in which firms or industries operate prompts them to alter their operations and this requires going through a complex process. "In order to analyse such situations, Miles and Snow developed a model called 'the adaptive cycle', [33], which is an attempt to generalize the psychology at work in the behavior of organizations."

The adaptive cycle identified three problems: 1) The entrepreneurial problem (domain definition), 2) The engineering problem (technology), and 3) The administrative problem (structure, process and innovation). Figure 1 highlights the Miles and Snow framework. 
THE ADMINISTRATIVE PROBLEM

Lagging aspect: Rationalization of struc-

ture and process
THE ENTREPRENEURL PROBLEM

Choice of product-market

domain

\section{4 \\ THE ENGINEERING PROBLEM \\ Choice of technologies for production and distri- \\ bution}

Figure 1. Miles and snow "Adaptive Cycle Framework".

\section{Leading aspect:}

Selection of areas for future;

Innovations.

\subsubsection{The Entrepreneurial Problem}

The adaptive cycle, though evident in all organizations, is perhaps most visible in new or rapidly growing organizations (and in organizations which recently have survived a major crisis). When organizations are setting up they are innovative because they are driven by entrepreneurial insight, which focusses on creating wealth by taking risks and innovatively seeking opportunities. The organization at this point will have defined goals, "perhaps only vaguely defined at first, must be developed into a concrete definition of an organizational domain: a specific good or service and a target market or market segment. In an on-going organization, the entrepreneurial problem has an added dimension. Because the organization has already obtained a set of "solutions" to its engineering and administrative problems, its next attempt at an entrepreneurial "thrust" may be difficult," [34].

\subsubsection{The Engineering Problem}

The engineering problem is concerned with how management of an organization will use technology to address the entrepreneurial problem. Entrepreneurship involves innovation and one of the ways in which to do this is through technology. Management in an organization requires a system which looks at which technology to adopt in order to satisfy the entrepreneurial issue. The engineering problem looks into how to innovatively produce a product, this includes aesthetics and design. To this end management needs to identify which technology to use to manufacture and produce it [34].

\subsubsection{The Administrative Problem}

The administrative problem involves the structure and processes in an organization. It is concerned with how these issues of strategy, structure, change, and processes impact an organization and how they can be used to reduce uncertainty in the work environment. In the Miles and Snow model, the administrative problem seeks to ensure rationalisation and stabilisation of organisation activities which enable the firm to solve the problems which arise during the entrepreneurial and engineering phases. 
The organisation needs to work through these phases of entrepreneurial problem, engineering problem and administrative problem in a coordinated manner in order to adapt. To do this the organisation should endeavour to have the right mix of administrative solutions to efficiently and effectively acclimatise. Miles and Snow established this by studying different industries and it through those studies that they identified four archetypes. "Each of these has its own strategy in responding to changes in the surroundings, and its typical configuration for technology, structure and process consistent with its strategy. Three stable situations are named "Defender", "Analyser" and "Prospector", where the company is competitive over time if organized according to its strategic type. The last category is called "Reactor" and represents an unstable situation," [33].

\section{Methodology}

The study followed a qualitative research design, using descriptive and correlation statistical methods to analysis the data. SPSS software package version 20 was used to analyze the results.

\subsection{Population and Sample Size}

The target population in this paper was drawn from the seven media houses in Zambia. Two state owned media houses and five private owned media houses. These included the Zambia Daily Mail, Times of Zambia as state owned. The five private media were the Daily Nation Newspaper, the Mast, News Diggers Newspaper, the Voice and the New Vision. The computed sample size from the employees in the seven media houses was 101 from a population of 180 . A questionnaire was used as the research instrument.

The researcher adopted a sample size using purposive sampling method. The function below used to compute the sample size [34].

$$
n=N / 1+N\left(e^{2}\right)
$$

Equation (1) was used to determine the sample size, where $\mathrm{n}$ is the sample size, $\mathrm{N}$ is the population and $\mathrm{e}$ is the level of precision. Based on $10 \%$ precision level, it gave a sample size of 101 out of 180 potential respondents representing a 100 percent response rate of the survey questionnaires. SPSS version 20 was used to analyze quantitative data. The specific statistical method used was descriptive statistics in SPSS. The researcher used quantitative data collection methods. In the quantitative method, the researcher used 101 structured and self-administered questionnaires to the 101 purposively randomly selected respondents.

Chi-Square tests and P-value were conducted using descriptive statistics in SPSS.

\subsection{Inclusion and Exclusion Criteria}

The study included members of staff who are directly linked to the production and revenue collection of the seven print media (Newspaper) firms. The study did not include those members of staff who are not directly linked to the core 
business of the newspaper such as procurement department.

\subsection{Research Conceptual Model}

Figure 2 below shows the proposed conceptual model based on Miles and Snow in [25] that was developed and used during the study.

\section{Results}

\subsection{Threat of Online Media on Printed Newspapers (Age and Digital Literacy)}

The study findings revealed that the age and digital literacy to an extent influenced the use of online media. Respondents between the age of 31 - 40 had a larger proportion of identifying with online media platforms (Table $1 \&$ Table 2).

Although it was not part of the purpose of the study, this set of data was intended to describe demographic variables of the sample and to assess for any influence on the research findings (Figure 3 ).

The Bar Chart above is an indication of the study's observed digital literacy levels of the respondents. As can be seen, most of the respondents are good in using the internet and computers.

\subsection{Assessment of How Online Media Affects Newspaper Business}

Out of 101 respondents $36 \%$ indicated that online media will reduce sales on printed newspapers. $30 \%$ showed that there will be no immediate effects or impact on sales because print newspapers are still enjoying favourable readership and market share in terms of advertising revenue. However, $21 \%$ of the respondents indicated that the impact will require for newspaper owners to put in place business strategies which will address the technological impacts on print newspapers, whereas, $13 \%$ indicated that online media will shift readers from print to online media because technology allows them to access more content online and at their convenience.

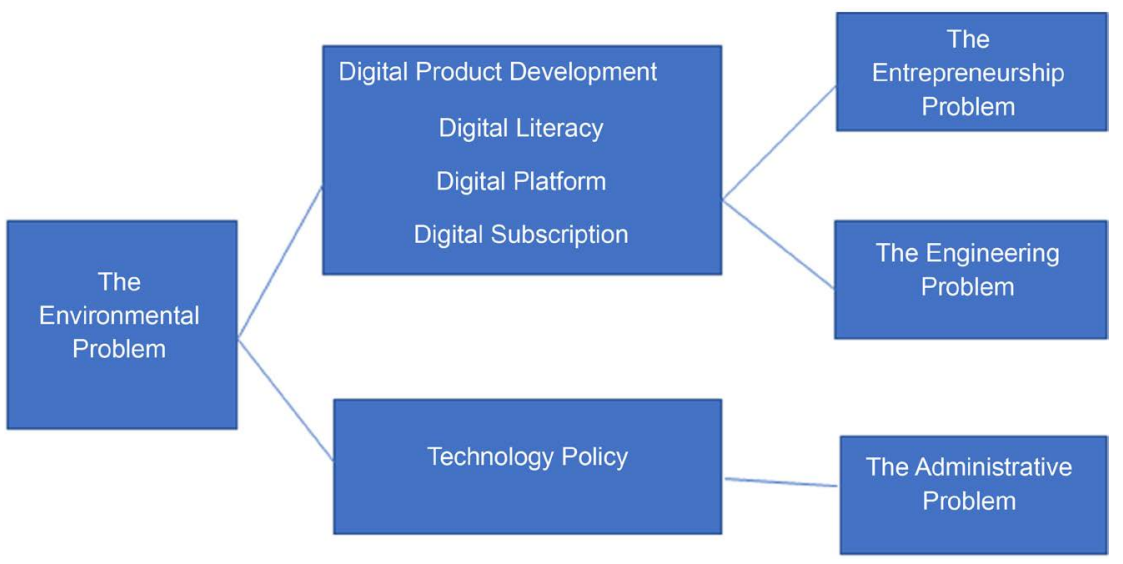

Figure 2. Print media survival business model for developing countries. 
Table 1. Distribution of study sample by age.

\begin{tabular}{ccc}
\hline & \multicolumn{2}{c}{ Age } \\
\hline 20 or under & Frequency & Percent \\
$21-30$ & 1 & 1 \\
$31-40$ & 34 & 33.7 \\
$41-50$ & 50 & 49.5 \\
$51-60$ & 13 & 12.9 \\
60 and Above & 1 & 1 \\
Total & 2 & 2 \\
\hline
\end{tabular}

Table 2. Socio-economic distribution of respondents.

\begin{tabular}{cccc}
\hline Variable & & Frequency & Percent \\
\hline \multirow{2}{*}{ Gender } & Male & 65 & 64.4 \\
& Female & 36 & 35.6 \\
& Secondary or High & 3 & 3.0 \\
Education & School and below & 52 & 51.5 \\
& Diploma First Degree & 38 & 37.6 \\
& Master's Degree & 8 & 7.9 \\
& Salaried Worker & 96 & 95 \\
& Self Employed & 4 & 4 \\
& Pensioner & 1 & 1 \\
& & 101 & 100 \\
\hline
\end{tabular}

\section{Digital Literacy}

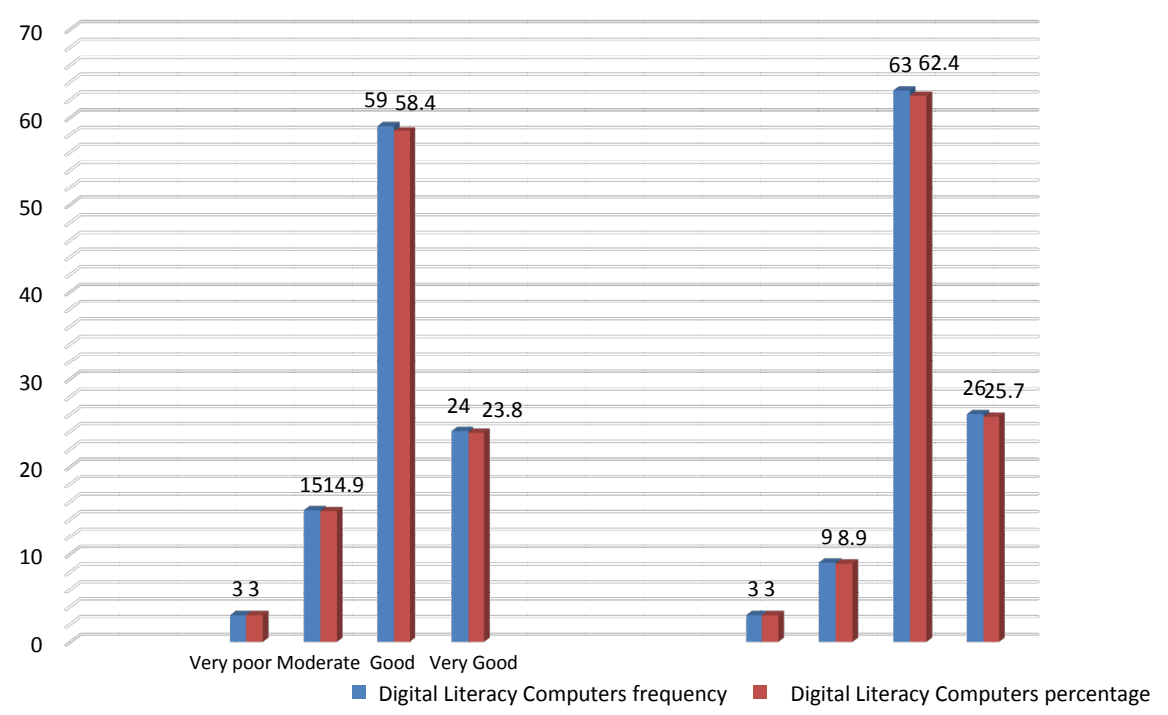

Figure 3. Digital literacy level of respondents.

Table 3 is a cross tabulation of E-paper usage and the impact of the E-papers on print media revenue collection. Respondents were asked whether they thought 
Table 3. Cross tabulation of E-paper use and price.

\begin{tabular}{|c|c|c|c|c|c|c|c|c|c|}
\hline & & & \multicolumn{7}{|c|}{ The e-paper should be free } \\
\hline & & & $\begin{array}{l}\text { Strongly } \\
\text { Disagree }\end{array}$ & Disagree & Neutral & Agree & $\begin{array}{l}\text { Strongly } \\
\text { Agree }\end{array}$ & $\begin{array}{c}\text { Not } \\
\text { Applicable }\end{array}$ & Total \\
\hline \multirow[t]{5}{*}{ E-paper } & Yes & Count & 51 & 20 & 7 & 5 & 2 & 7 & 92 \\
\hline & & $\%$ of Total & $50.50 \%$ & $19.80 \%$ & $6.90 \%$ & $5.00 \%$ & $2.00 \%$ & $6.90 \%$ & $91.1 \%$ \\
\hline & No & Count & 3 & 1 & 1 & 0 & 2 & 2 & 9 \\
\hline & & $\%$ of Total & $3.00 \%$ & $1.00 \%$ & $1.00 \%$ & $0.00 \%$ & $2.00 \%$ & $2.00 \%$ & $8.90 \%$ \\
\hline & & Count & 54 & 21 & 8 & 5 & 4 & 9 & 101 \\
\hline Total & & $\%$ of Total & $53.50 \%$ & $20.80 \%$ & $7.90 \%$ & $5.00 \%$ & $4.00 \%$ & $8.90 \%$ & $100 \%$ \\
\hline
\end{tabular}

the E-paper should be accessed free of charge. The results show that 50.5\% strongly disagreed, $19.8 \%$ disagreed, and only $5 \%$ and $2 \%$ agreed and strongly agreed. Additionally, these results show that a higher proportion of both who use and do not use the E-paper in their business indicate that they E-paper should not be offered free. By observation, there should not be free access to the E-paper by online users.

Table 4 shows the statistical analysis of the effect of Online Media on Print Media based on the proposed conceptual model in Figure 2.

According to the Chi-Square test, the observed P-value of 0.034 is less than the level of significance of $5 \%$ and we conclude that there is evidence to suggest, Online media inform form of E-Paper has an effect on the print media.

\subsection{Effects of Online Media on Printed Newspaper Business}

The results show that $35 \%$ of the respondents indicated that shifts in technology and innovation, have made it easier for people to access information online and made it convenient for users. The results show that $21 \%$ are of the view that online media has increased the number of people reading newspapers both online and hard copy, whereas, $27 \%$ indicated that lack of internet access and knowledge on how to use the internet has reduced the impact of online media on newspaper businesses in developing countries like Zambia. Only 6\% of the respondents observed that online media will not change newspaper business. The results indicate that $53 \%$ of respondents have seen no change in the number of adverts they receive from advertisers despite increase in use of online media.

On the other hand, results in Figure 4, indicate effects of online media on newspaper advertisement: $53 \%$ of respondents indicated that there has been no change in the number of adverts they receive from advertisers despite increase in use of online media. $19 \%$ of the respondents said adverts in their newspapers have increased, whereas, 14 percent feel that there is some change to the effect that advertisers now prefer digital or online platforms to advertise. This corresponds with the remaining 14 percent of respondents who believe that advertisement in their newspapers has reduced. 
Table 4. Pearson chi-square test on the effect of online media on print media.

\begin{tabular}{cccc}
\hline & \multicolumn{3}{c}{ Chi-Square Tests } \\
\hline Pearson Chi-Square & $12.095 \mathrm{a}$ & 5 & Asymp. Sig. (2-sided) \\
Likelihood Ratio & 8.374 & 5 & 0.034 \\
Linear-by-Linear Association & 5.593 & 1 & 0.137 \\
N of Valid Cases & 101 & & \\
\hline
\end{tabular}
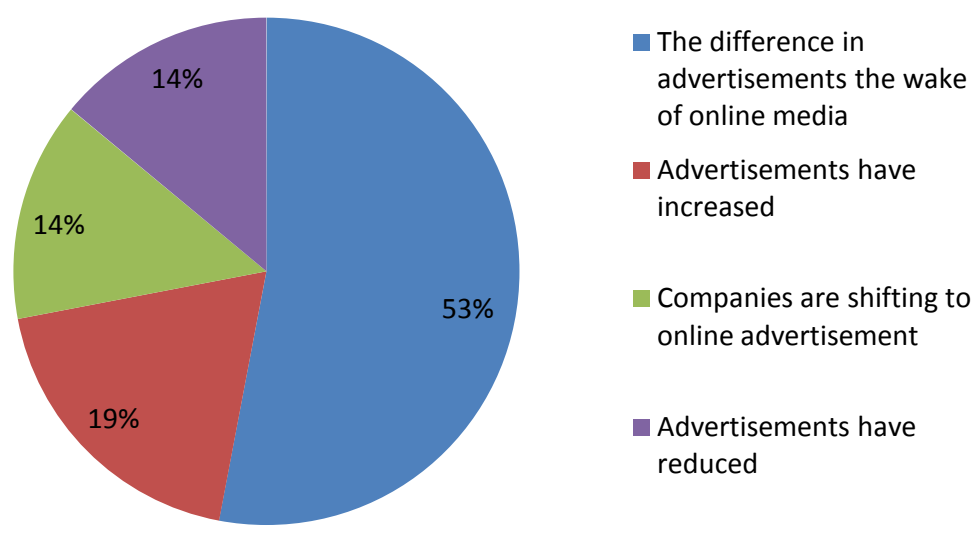

Figure 4. Effects of online media on print newspaper advertisement.

\section{Discussions and Conclusion}

From the analysis of the results, it has been established that age has an influence on the threat of online media and survival of printed media. It was discovered that majority of the young people use digital devices and hence, spend more time online than the older generation. Most of the younger population are in some form of employment and hence much busier and would rather use their mobile phones, laptops and computers to access online information than to buy the newspaper. The study also indicates that as more people flock to online spaces for information, sales of the printed newspaper was reducing. This will negatively impact the revenue collection of the newspapers. This is because advertisers want to reach a wide audience and if the printed newspapers are not doing that for them, they will move to the platform where they will find the clients. It was also observed that many advertisers are moving to digital spaces to advertise their products and services and that this is negatively impacting the printed newspaper as revenue will continue to decline if business strategy is not addressed.

\section{Recommendations}

The Miles and Snow framework gives a basis and understanding on how firms should operate and what they need to do to survive. This study has shown that there an impact on revenue for the print media from online media in developing countries. There is therefore need to have the right mix of the factors in order to 
survive. For the print media in developing countries to survive it needs to sale its products. It is important that these companies in developing countries like Zambia devise a plan which enables digital citizens to access news content online by paying for it. They need to move away from providing content free and instilling a culture where people trust the newspapers content. This can be done by providing accurate and exclusive content. Print media industry in developing countries should embrace technology and formulate strategies to improve on customer base from online audience.

\section{Acknowledgements}

We would like to acknowledge all the seven print media houses in Zambia that participated in this study.

\section{Conflicts of Interest}

The authors declare no conflicts of interest regarding the publication of this paper.

\section{References}

[1] Mwiya, M., Phiri, J. and Lyoko, G. (2015) Public Crime Reporting and Monitoring System Model Using GSM and GIS Technologies: A Case of Zambia Police Service. International Journal of Computer Science and Mobile Computing, 4, 207-226.

[2] Mpolokoso, A. and Phiri, J. (2018) Managing Customary Land Conflicts and Demarcations Using Mobile Applications Tools: A Case Study of Zambia. International Journal of Wireless and Mobile Computing, 15, 323-334. https://doi.org/10.1504/IJWMC.2018.10018287

[3] Simukanga, A., Phiri, J., Nyirenda, M. and Kalumbilo-Kabemba, M.M. (2018) E-Governance Systems: A Case Study of the Development of a Small-Scale Farmer Database. Zambia ICT Journal, 2, 7-15.

[4] Soneka, P.N. and Phiri, J. (2019) A Model for Improving E-Tax Systems Adoption in Rural Zambia Based on the TAM Model. Open Journal of Business and Management, 7, 908-918. https://doi.org/10.4236/ojbm.2019.72062

[5] Adner, R. (2006) Match Your Innovation Strategy to Your Innovation Ecosystem. Harvard Business Review, 84, 98-107, 148.

[6] Alejandro, J. (2010) Journalism in the Age of Social Media. Reuters Institute Fellowship Paper, University of Oxford, Oxford.

[7] Babbie, E.R. and Mouton, J. (2007) The Practice of Social Research. 11th Edition, Oxford University Press, Cape Town.

[8] Chari, T. (2009) The Future of the Printed Newspaper in the Context of the Internet in Africa: The Case of Zimbabwe.

[9] Ernst \& Young LLP (2011) The Digitisation of Everything. How Organisations Must Adapt to Changing Consumer Behaviour. London.

[10] Gant, A. (2018) The Future of the New Media Economy: Exploring the Entanglement of Advertising and Journalism Professionals via the Phenomenon of Native Advertising. Lund University, Lund.

[11] Chyi, H.I. (2005) Willingness to Pay for Online News: An Empirical Study on the Viability of the Subscription Model. Department of Journalism and Communica- 
tion, the University of Arizona, Tucson. https://access.astrialibrary.com/s/unza-gsb

[12] Cheria, J. and Farouk, S. (2015) Proliferation of E-Newspapers and Its Financial Impact on the Publishing Industry in UAE. International Journal of Economics and Finance, 7, 194-198. https://doi.org/10.5539/ijef.v7n3p194

[13] Lehtisaari, K., Karppinen, K., Harjuniemi, T., Grönlund, M., Lindén, C.-G., Nieminen, H. and Viljakainen, A. (2012) Media Convergence and Business Models: Responses of Finnish Daily Newspapers. Helsinki University Print, Helsinki.

[14] Krumsvik, A. (2006) What Is the Strategic Role of Online Newspapers? Nordicom Review, 27, 283-295. http://www.researchgate.net/publication/242102867

[15] Sparano, M.T. and Takashi, K.H. (2010) An Analytical Framework for Miles and Snow Typology and Dynamic Capabilities. Enanpad, Rio De Jeneiro.

[16] Miles, R.E., Snow, C.C., Meyer, A.D. and Coleman, H.J.R. (1978) Organizational Strategy, Structure, and Process. Academy of Management Review, 3, 546-562. https://doi.org/10.2307/257544

[17] Media Institute for Southern Africa (MISA) (2012) Media Barometer Zambia 2012. MISA, Windhoek.

[18] Christian, M. (2012) Social Media and Journalism. From Traditional to Online Media: Best Practices and Perspectives. 14th Central Asia Media Conference, Ashgabat, 5-6 July 2012. https://www.osce.org/fom

[19] Mugenda, O.M. and Mugenda, A.G. (2003) Research Methods: Quantitative and Qualitative Approaches. African Centre for Technology Studies, Nairobi. http://blog.nielsen.com/nielsenwire/global

[20] Geoffrey, N.T. (2014) A Comparative Study of Print and Online Media Content in Kenya: A Case of "Daily Nation" Newspaper. University of Nairobi, Nairobi.

[21] Nkomo, N.Z., Kandiro, A. and Bigirimana, S. (2017) The Viability of the Print Newspaper in the Digital Era in Zimbabwe: A Digital Strategy Perspective. European Journal of Business and Innovation Research, 5, 39-61.

[22] Organisation for Economic Co-operation and Development (2012) The Digital Economy. Competition Committee Sessions of October 2011 and February 2012.

[23] European Centre for Research Training and Development UK Northeast Ethics Education Partnership (NEEP) (2012) Privacy and Confidentiality: Issues in Research.

[24] Palinkas, L.A., Horwitz, S.M., Green, C.A., Wisdom, J.P., Duan, N. and Hoagwood, K. (2015) Purposeful Sampling for Qualitative Data Collection and Analysis in Mixed Method Implementation Research. Administration and Policy in Mental Health, 42, 533-544.

[25] Esa, R. (2016) Digital News Report, Finland. Reuters Institute, Oxford. http://www.digitalnewsreport.org/survey/2016/finland

[26] Sandi (2014) Times of Zambia e-Paper: Read All about It. https://www.techtrends.co.zm/times-zambia-e-paper-now-read/

[27] Simutanyi, N., Fraser, A. and Milapo, N. (2015) Background Paper: Politics and Interactive Media in Zambia. PiMA Working Paper \#3, University of Cambridge, Centre of Governance and Human Rights, Cambridge.

[28] Singer, J. (2003) Who Are These Guys? The Online Challenge to the Notion of Journalistic Professionalism. Journalism, 4, 139-163. https://doi.org/10.1177/146488490342001

[29] The Nielsen Company (2018) Survey on Online Media Landscapes. https://www.nielsen.com/us/en/contact-us/panels.html 
[30] Preethi, T. (2014) The Impact of New Media on Traditional Media Illinois Institute of Technology. Middle-East Journal of Scientific Research, 22, 609-616.

[31] Rose, W., Graham, C., Sue, H. and Vikki, C. (2006) Anonymity and Confidentiality. ESRC National Centre for Research Methods. http://www.pressreference.com

[32] Quinn, S. (2004) An Intersection of Ideals: Journalism, Profits, Technology and Convergence. Convergence, 10, 109-123. https://doi.org/10.1177/135485650401000409

[33] Quocirca (2016) Digital Transformation: Bridging the Paper and Digital Gap. Quocirca Ltd.

[34] Zambia Daily Mail Limited (2015) Strategic Plan 2015-2010. Zambia Daily Mail Limited, Lusaka. 